\title{
1. Carbon tax choices: the tale of four states
}

\author{
Janet E. Milne*
}

During 2015 and 2016, carbon tax proposals were presented to the legislatures of six states in the United States - Vermont, ${ }^{1}$ Massachusetts, ${ }^{2}$ Rhode Island, ${ }^{3}$ New York, ${ }^{4}$ Oregon ${ }^{5}$ and Washington. ${ }^{6}$ The legislatures did not bring the measures to a vote, but the proposal in Washington was presented directly to voters at the ballot box in November 2016. This analysis explores how state constitutions can influence choices governing the design of carbon tax proposals and the procedural path that they take toward enactment. For the sake of simplicity, it focuses on bills from Oregon, Massachusetts, Vermont and Washington to explore an array of constitutional issues.

\subsection{A BRIEF OVER VIEW OF THE CARBON TAX PROPOSALS}

Proponents of carbon taxes have chosen a variety of names for the proposed carbon pricing instruments, such as a tax on carbon-based fuels, ${ }^{7}$ a carbon pollution tax, ${ }^{8}$ a carbon dioxide emissions charge ${ }^{9}$ and a carbon fee. ${ }^{10}$ As discussed below, the choice of terminology does not dictate the legal character of a measure, but it presumably does reflect a political calculation. This analysis will refer to the proposals collectively as carbon taxes, but that formulation is not meant to reflect a bias about whether the measures are in fact taxes, fees or charges for purposes of constitutional analysis.

All of the proposals focus on carbon dioxide emissions from the combustion of fossil fuels, although the Massachusetts bill extends the tax base to some other greenhouse gas emissions. However, the proposals vary in terms of which sectors they cover. Vermont and Massachusetts largely exclude the emissions from the electricity-producing sector, while the proposals in Oregon and Washington are economy-wide. This difference is likely due to the fact that Vermont and Massachusetts participate 
in the Regional Greenhouse Gas Initiative, a cap-and-trade program for large-scale power plants of a certain size in nine states, that already places a price on carbon dioxide emissions from electricity generation. ${ }^{11}$

All of the proposals apply the tax at the upstream point of sale or distribution within the state. The tax rates vary from state to state, but all are quite substantial. When fully phased in, the maximum tax rates are: $\$ 40$ per ton of $\mathrm{CO}_{2} \mathrm{e}$ in Massachusetts (subject to reevaluation thereafter); $\$ 60$ per ton of carbon under one Oregon proposal (House Bill 3252); and $\$ 100$ per metric ton of $\mathrm{CO}_{2}$ in Vermont and Washington. ${ }^{12}$ Another Oregon proposal (House Bill 3176) increases the $\$ 30$ tax per metric ton of $\mathrm{CO}_{2}$ by $\$ 10$ a year and sets no cap. The proposals use the revenue differently. The proposals in Massachusetts and Washington and House Bill 3176 in Oregon are revenue neutral and distribute the revenue back to taxpayers or residents through tax cuts or rebates. House Bill 3252 in Oregon takes the opposite approach and would use all of the revenue for designated spending programs. The Vermont bills take a middle approach. They distribute the vast majority of the revenue to taxpayers and employers and allocate a minority to climate-related spending programs.

Finally, the proposals take different approaches to the question of who is responsible for implementation and administration. The Vermont and Washington bills put the responsibility in the hands of tax authorities. The Massachusetts bill gives the Commissioner of Energy Resources administrative responsibility. The two Oregon proposals take a hybrid approach, assigning responsibility to the Department of Revenue but identifying roles for the Public Utilities Commission, in one case, and the Department of Energy, in the other.

The theme explored below is the extent to which state constitutions can shape choices about the design features of carbon taxes, choices about the carbon tax proposals' political route through the legislative process, and choices about whether to use carbon taxes or cap-and-trade programs. Carbon taxes have entered the state policy landscape as a "new kid on the block", but in entering the scene, they must live by constitutional rules governing the existing, well established fiscal players - or wait for a change in the rules. The carbon tax proposals in Oregon, Massachusetts and Vermont illustrate how the new kid faces old constitutional constraints in substantive and political respects. The proposal in Washington demonstrates how a state constitution can provide strategic political procedural opportunities. 


\subsection{CONSTITUTIONAL LIMITS ON DESIGN CHOICES}

Oregon's constitution contains provisions that significantly influence the substantive design features of proposals for state-level carbon taxes. Those provisions were the product of policy decisions approved by the voters in the twentieth century before climate change and carbon pricing entered the policy arena, but they nonetheless apply to any carbon taxes that the state might consider.

One provision limits the rate of taxes that can be applied to certain fossil fuels. The constitution provides that the maximum tax rate on the sale or use of oil and natural gas is six percent of the market value of oil and natural gas produced in the state. ${ }^{13}$ Enacted in 1980 in order to help finance the Common School Fund, the provision nonetheless would seem to apply to carbon taxes on oil or natural gas. ${ }^{14} \mathrm{~A}$ lingering legal issue is whether the constitutional limit on the tax rate applies only to fuel extracted in the state. ${ }^{15}$ If so, the constitutional restriction would have limited effect, given that relatively little natural gas and no oil is extracted in the state. ${ }^{16}$ However, applying a higher tax rate to oil and gas that enters the state through interstate commerce presumably would violate the federal constitution's dormant commerce clause, which prevents states from discriminating against interstate commerce. As a result, Oregon's constitutional limit on the tax rate may suppress the carbon tax rate for all oil and natural gas consumed in the state regardless of the place of production. ${ }^{17}$

The Oregon Constitution also limits policymakers' flexibility to decide how to use the revenue from a carbon tax. Under the 1980 constitutional amendment, revenue from taxes on oil and natural gas must be used to finance school systems (subject to the lingering question of whether this limit applies to fuels produced out-of-state). ${ }^{18}$ In addition, a constitutional amendment dating back to 1942 requires that revenue from taxes on motor vehicle fuels must be dedicated to the construction, maintenance, operation and use of highways, roads and roadside rest areas, ${ }^{19}$ reflecting a desire on the part of voters "to guarantee that none of the 'proceeds' of the taxes and fees listed in the amendment would be diverted to any other purposes." ${ }^{20}$ Oregon is not alone in earmarking gas tax revenue to transportation purposes. ${ }^{21}$

Although designed to achieve other policy goals, these constitutional provisions impose significant limitations on the design of Oregon's carbon tax proposals. The two proposals for carbon taxes in Oregon address these limits in different ways. In terms of the cap on the tax rate, House Bill 3252 specifically limits the tax rate for oil and natural gas to the six-percent cap 
and refers to the constitutional limit. ${ }^{22}$ House Bill 3176 calls for a "fee" and does not contain any explicit limit; it instead includes a general provision stating that the fee does not apply to fuels that the state cannot tax as a matter of constitutional law. ${ }^{23}$

With respect to the constitutional requirements for how revenue from taxes on gasoline must be used, House Bill 3252 appears to accept and adapt to the limit. The bill requires that revenue from carbon taxes on motor vehicle fuels will be used for a variety of transit-related purposes, such as electrifying road transport through the installation of charging stations and providing lanes for bicycles and buses. ${ }^{24}$ Although the Oregon Supreme Court interprets the constitutional provision narrowly, ${ }^{25}$ it has implied that some transportation demand management projects, such as bus lanes, may be permissible. ${ }^{26}$ Under this line of reasoning, the bill's choice of spending projects that have an identifiable policy linkage to road systems could be defensible, but it could still be susceptible to a legal challenge - a question that ultimately only the court can resolve. To the extent that the revenue is not subject to a constitutionally mandated use, the bill directs the revenue to low-income assistance programs, carbon mitigation programs and green jobs. ${ }^{27}$

By contrast, House Bill 3176 would distribute virtually all of the revenue from its "fee" back to individual taxpayers in equal shares, ${ }^{28}$ following a revenue-neutrality principle. The bill does not specifically recognize the constitutional limitations on revenue use, which would make this use of the revenue constitutionally suspect. ${ }^{29}$ Alternatively, it is possible that proponents of House Bill 3176 characterized the measure as a "fee" in order to avoid the constitutional limits - or at least to provide an opportunity to argue that the limits do not apply. It appears unlikely, however, that the designation of the carbon levy in House Bill 3176 as a "fee" would avoid the requirement that "taxes" on motor vehicle fuel must be used for road transportation purposes. The Oregon Supreme Court has firmly stated that "no matter what label the legislature may attach to a tax on motor vehicle fuel, whether it be 'fee,' 'excise,' 'tithe,' 'assessment' or some other term, the revenues derived therefrom must be dedicated to the listed purposes". ${ }^{30}$

Thus, these state constitutional limitations place real constraints on carbon tax design. Limits on the tax rate can diminish the strength of the price signal. Limits on the use of the revenue reduce the range of policy choices, but mandated dedication of some of the revenue to transportation purposes has the potential to align with climate change goals. If proponents of carbon taxes wish to escape the limits, they have the option of leading a campaign to amend the constitution - a path they have pursued, so far unsuccessfully. A proposal to amend the constitution to allow the 
legislature to impose carbon taxes and use the revenue for a wide range of purposes was introduced in the Oregon House of Representatives in 2015 but did not move forward. ${ }^{31}$ The new kid on the block must continue, for now, to live by the old rules.

\subsection{CONSTITUTIONAL ALLOCATION OF LEGISLATIVE POWER AND DESIGN IMPLICATIONS}

Carbon taxes are the product not just of abstract policymaking but also the very real influences of the political landscape. One of the key factors for success is having strong proponents in the legislature who can propose the measure, convince colleagues of its value and find strategic opportunities to advance its journey through the legislative process. A provision present in about 20 state constitutions ${ }^{32}$ affects the constitutional rulebook by which this legislative game is played. Under what is known as the "origination clause", the House of Representatives in the bicameral state legislature must take the first move in voting on certain fiscal measures.

This constitutional procedural rule can be strategically significant. For example, if the strong carbon tax proponents are in the Senate, not the House, they cannot build momentum by bringing their measure to a vote until the House has acted. ${ }^{33}$ Thus, if strategic political opportunities to move carbon taxes forward lie more in the Senate than the House, one must consider the scope of the origination clause and whether there are ways to design carbon taxes or other pricing mechanisms that fall beyond its reach. The discussion below considers the origination clause implications for carbon tax proposals in the four states.

Three out of the four states' constitutions have an origination clause, but they use slightly different terms to describe the bills that must originate in the House of Representatives. The Massachusetts Constitution refers to "money bills"; $; 4$ the Oregon Constitution refers to "bills for raising revenue" 35 (as does the federal constitution ${ }^{36}$ ); and the Vermont Constitution uses the term "Revenue bills". ${ }^{37}$ The Washington Constitution, however, allows either chamber to originate any type of bill. ${ }^{38}$ The rationale for these longstanding origination clauses lies in the desire to enhance political accountability for fiscal decisions. As the Oregon Supreme Court has stated: "[b]ills for raising revenue are required to have their origin in the lower branch of the legislature because it is the more numerous of the two bodies, and, being oftener renewed by elections, presumptively it more closely and directly represents the people." ${ }^{39}$ 
In the carbon tax context, the question is which carbon pricing mechanisms will be subject to this procedural requirement and whether certain design features can allow a revenue measure to sidestep the origination clause. If carbon pricing instruments are "money bills", "revenue bills" or "bills for raising revenue", depending on the jurisdiction, they will be subject to the origination clause. The legal meaning of these terms is not infrequently the subject of litigation.

The carbon tax bills introduced in Oregon and Vermont were all filed in the House of Representatives, so the origination clause, if applicable, was de facto satisfied. In Massachusetts the bill was filed in the Senate, potentially provoking the question whether the Senate would be barred from voting on the proposal on the grounds that the proposal is a "money bill" for origination clause purposes. As events unfolded, the bill was not brought to a vote in the Senate before the close of the 2016 legislative session for other reasons. To illustrate the potential design implications of the origination clause, however, the discussion below briefly explores whether the Massachusetts origination clause might apply to the carbon dioxide emissions charge proposed in Massachusetts.

The Supreme Judicial Court of Massachusetts has said that a bill is a "money bill" under the origination clause if it falls within "the narrow meaning that the Justices have ascribed to this term in the past: it 'transfer[s] money or property from the people to the State" ${ }^{40}$ Because governments can receive money through different types of legal instruments, the legal challenge lies in determining which revenue-generating instruments fall within the origination clause's reach. Courts interpreting origination clauses, including the Supreme Judicial Court of Massachusetts, frequently cite Justice Story's discussion in his Commentaries on the Constitution of the United States (1833): "The history of the origin of the power already suggested abundantly proves that it has been confined to bills to levy taxes, in the strict sense of the word, and has not been understood to extend to bills for other purposes, which may incidentally create revenue." 41 Thus, fees for government services do not fall within the origination clause despite the fact that money will go to the treasury. ${ }^{42}$ However, the name that the governing body has attached to a levy will not definitively determine whether it is a tax or a fee for constitutional purposes. A court will look instead to the manner in which it operates. ${ }^{43}$

Even if the payment to the government takes the form of a tax, the origination clause may not apply. Some courts will look at the purpose of the bill to determine whether the tax is incidental to the bill's purpose. In effect, they look not just at whether there is a tax measure that raises revenue but whether the bill as a whole is primarily designed for raising revenue. The Supreme Judicial Court of Massachusetts has taken this approach. In a 
recent advisory opinion, the court stated that: "a bill devoted to another purpose or purposes that 'incidentally create[s] revenue' is not a money bill." 44 It determined that a measure that deferred the effective date of a tax deduction would transfer money to the government for constitutional purposes, but it also looked at whether that measure was incidental to the purposes of the larger budget bill within which it resided. It concluded that the tax measure was not incidental. When characterizing measures that are incidental, it wrote that: "the types of bills that we and the United States Supreme Court have situated in this category have been devoted to specific, well-defined programs and goals. ${ }^{\prime 45}$

Note, however, that not all courts will consider the tax measure in light of the broader purposes of the legislation. The Supreme Court of Oregon looks at two issues. "The first is whether the bill collects or brings money into the treasury. If it does not, that is the end of the inquiry. If a bill brings money into the treasury, the remaining question is whether the bill possesses the essential features of a bill levying a tax." 46 It has declined to go further and consider the primary purpose of the legislation. ${ }^{47}$

To some extent, the Massachusetts carbon dioxide emissions charge looks like a tax. It imposes a cost on payers that goes into the government purse. Moreover, it is not a traditional fee for a service that the government provides in return. However, there are plausible arguments why this bill is not a "money bill" for origination clause purposes. For example, the primary purpose of the charge is not to raise money for the government but rather to reduce greenhouse gas emissions. In fact, all of the revenue is returned to residents and businesses in Massachusetts through rebates, reinforcing the conclusion that any revenue-raising function is incidental to the charge's environmental purpose. Drawing on federal precedent, one can argue that even a charge that raises substantial revenue is not subject to the origination clause when its primary purpose is to change behavior. ${ }^{48}$

Alternatively, one might argue that the charge-and-rebate proposal is an environmental instrument that is very different from a tax or a fee. It is one cohesive environmental instrument that operates as a result of the cumulative incentive effect of both the charge and the rebate. The charge will encourage people to reduce their consumption of fossil fuels and reap immediate savings by avoiding tax. The pro-rata, per-capita rebate (or per-employee rebate in the case of businesses) will create a further incentive to use less fossil fuel and pay fewer charges: if people pay less tax than the statewide average, their per capita rebate will exceed what they paid in charges. They will benefit not only from avoiding taxes but also from receiving a cash reward. Thus, the revenue-generating side of the instrument cannot be separated from the revenue-using side. As a result, the 
combination creates a behavioral environmental instrument that looks quite different to a tax, especially when viewing a tax "in the strictest sense of the word" for origination clause purposes.

The allocation of administration of the charge to non-tax authorities can also reinforce arguments that the charge is not a tax. The Massachusetts bill placed primary responsibility for administration of the charge in the hands of the Commissioner of Energy Resources.

To reduce the risk that a proposal will be subject to an origination clause challenge, the following design choices may be influential, even if not legally definitive in any particular jurisdiction. First, closely integrating the rationales for the carbon price and the use of the revenue may increase the opportunity to portray the instrument as something other than a tax that raises revenue. This tact would tilt toward using the revenue to remediate the damage caused by the payers (reaching to the boundaries of legal fee theory), or using a revenue rebate as part of the calculation of the behavioral impact of the charge (on the grounds that the instrument as a whole is something other than a tax or fee). Second, presenting the carbon price instrument as an element of a larger carbon policy package may render any tax-like features incidental to the regulatory purpose of the legislation as a whole. Third, selecting a non-tax agency to administer the payment system can maximize its environmental credentials. Conversely, it may be wise to avoid design features that are more likely to signal a traditional tax bill, such as a revenue-neutral tax shift or using the revenue for a mix of new spending and taxpayer relief.

\subsection{THE INFLUENCE OF CONSTITUTIONAL SUPERMAJORITY VOTING REQUIREMENTS}

The legislatures in Vermont and Massachusetts can pass tax legislation by simple majority. Some state constitutions, however, require both chambers of the legislature to approve certain fiscal measures by supermajority vote. For example, Oregon's constitution requires an affirmative vote by three-fifths of each house of the legislature "to pass bills for raising revenue" 49 (the same term it uses for its origination clause). Both carbon pricing proposals in Oregon address this issue in their introductory language, stating that the bills are "providing for revenue raising that requires approval by a three-fifths majority". ${ }^{50}$ Given that the Oregon Supreme Court applies a relatively broad interpretation of what constitutes a tax which does not consider the purpose of the charge, as discussed above, one would have to construct the charge as a fee, narrowly defined, to escape the supermajority requirement. 
Supermajority voting requirements for taxes (or fees) may create an incentive to instead pursue cap-and-trade regimes. Opting for a capand-trade regime, however, may still mean facing the risk of litigation over whether a supermajority requirement still applies, as illustrated by litigation in California. California's cap-and-trade program auctions allowances for greenhouse gas emissions and uses the revenue for climate change mitigation programs. Opponents of the cap-and-trade regime have argued in court that auctioning the allowances is tantamount to imposing a tax and, therefore, that the regime should have been approved by supermajority vote. ${ }^{51}$ When the law was passed, California's constitution provided that "any changes in State taxes enacted for the purpose of increasing revenues" require a two-thirds vote of each house of the legislature. ${ }^{52}$ The trial court considered whether the auctioned allowances were created for the purpose of "increasing revenue". ${ }^{53}$ It concluded that the primary purpose of the trading program is regulatory even though the program would generate revenue, and it upheld the program. ${ }^{54}$

This decision has been appealed to the California Court of Appeal. ${ }^{55}$ The outcome may influence decisions about whether to choose carbon taxes or cap-and-trade regimes. Although other jurisdictions with supermajority voting requirements for revenue-raising provisions may have different constitutional language and precedent, the court's decision will likely send a strong signal about the legal characterization of cap-andtrade programs and how state constitutions can affect carbon pricing design choices. If auctioned allowances are deemed to lie outside the boundaries of taxes and fees, policymakers may have a political incentive to prefer cap-and-trade if they cannot garner more than a simple majority for carbon pricing.

\subsection{THE CONSTITUTIONAL OPPORTUNITY FOR VOTERS TO MAKE THE CHOICE}

In the normal course of events in Western democracies, legislatures choose among climate change policy instruments or adopt framework legislation that allows administrative agencies to execute the details. Those legislatures may be subject to the types of constitutional procedures discussed above. Some state constitutions in the United States, however, also offer citizens the opportunity to have the final vote on legislation, shifting the ultimate law-making power from the legislative body to the general public. As the carbon tax proposal in Washington illustrates, the Washington Constitution offers residents this opportunity.

The Washington Constitution reserves for the people the right to enact 
laws through an initiative process. ${ }^{56}$ The proposal for a revenue-neutral carbon tax in Washington, I-732, followed this initiative procedure, which is codified in enabling legislation. ${ }^{57}$ The proponents of the carbon tax were required to gather a minimum number of signatures - eight percent of the total votes cast in the last gubernatorial election (or 246,372 in 2015) ${ }^{58}$ which they succeeded in doing by the end of 2015. The initiative was then certified to the legislature, which had three choices. It could adopt the measure as law; it could choose not to act, in which case the measure would go to the voters during the next election cycle (November 2016); or it could propose an alternative, which would appear on the ballot in the next election cycle along with the original initiative proposal. ${ }^{59}$

When presented with the certified initiative, the Washington legislature did not act on the initiative. As a result, it appeared on the voters' ballots in the election on 8 November 2016. The language that appeared on the ballot was a brief summary of the initiative measure:

Initiative Measure No. 732 concerns taxes. This measure would impose a carbon emission tax on certain fossil fuels and fossil-fuel-generated electricity, reduce the sales tax by one percentage point and increase a low-income exemption, and reduce certain manufacturing taxes. Should this measure by enacted into law? Yes [] No [ ${ }^{60}$

Over 1.2 million people voted for the measure, but 59 percent voted against it ${ }^{61}$ If voters had approved the measure by a simple majority, the language in the 26-page initiative would have become law without any further action by the legislature. ${ }^{62}$

This initiative process opens an important strategic door for carbon pricing proponents. If the legislature does not have the political will to act, or if the legislature suffers from gridlock, the people themselves can launch an effort to move the idea forward. While this approach provides political opportunities, it also underscores the issue of institutional expertise. Under the traditional theory of decision making in a democracy, the legislature serves as the delegated decision maker, and in that capacity, often develops institutional expertise on issues of public interest. The decision makers are then accountable for their policymaking actions when they are next up for election. Under the initiative approach, however, the decision making is moved directly to the voters, who may or may not have the expertise to make the policy judgments and to assess relative policy priorities. In some respects, one could think of the initiative process as taking the theory of the origination clause one step further. The origination clause sought to place the first-mover responsibility in the hands of the legislative body closest to the voters. The initiative process places it directly in the hands of the voters. 


\subsection{CONCLUSION}

Constitutions can impose substantive design limits not intended to apply to carbon taxes but which can significantly influence carbon tax policies vestiges of the past that carry forward and limit the freedom to design. They can also create procedural barriers, through origination clauses and supermajority voting requirements. These requirements apply equally to all tax measures. They are not unique to carbon taxes, but in some political contexts, they can pose challenges. The response may be to try to design the carbon pricing measures to avoid those procedural barriers in the legislature. However, if the legislature is not politically responsive to carbon taxes, state constitutions may offer the opportunity to take the issue directly to the voters through voter-driven initiatives. Thus, constitutional requirements can shape both design features and the legislative route toward enactment.

The constitutional limitations reflect a certain degree of skepticism toward taxes. Constitutional mandates on maximum tax rates and the use of the revenue suggest that voters want to hold control over taxation in a tight grip, not easily loosened by politicians. Origination clauses keep accountability for taxes politically closer to voters, and supermajority requirements raise the political bar for passage. This constitutional patina of tax antipathy or skepticism may subtly tilt the constitutional scale away from carbon taxes and toward other climate policies.

Thus, dry constitutional language, often the product of pre-climate change policies, can influence carbon pricing choices - the design of the instrument, its fundamental character as a tax or fee, or the choice of another instrument entirely. Whether the constitutional considerations are significant will depend, of course, on the specific state's constitution. The significance of the procedural limitations will also depend on the political context. If there is strong leadership in the House of Representatives that supports carbon taxes, and if a legislative majority or supermajority favors the concept, the constitutional limits will fade into the background. But if leadership is scattered and the debate is contentious, they will carry more weight.

These constitutional twists in the state-level carbon tax plot contribute to the possibility that different states will make different design choices if they pursue carbon pricing. In the ideal world, the federal government would institute uniform carbon pricing that would transcend the patchwork of state policies, state politics and the limits of state constitutions. In the face of federal inaction, however, states can operate within their constitutional frameworks and still serve as valuable laboratories for policy development. 


\section{NOTES}

* The author thanks Patrick Marass for his research assistance. Any errors or omissions remain at the author's door.

1. H. 412, 73rd Gen. Assemb., Biennial Sess. (Vt. 2015-16); H. 395, 73rd Gen. Assemb., Biennial Sess. (Vt. 2015-16).

2. S. 1747, 189th Gen. Court, Reg. Sess. (Mass. 2016) [hereinafter S. 1747].

3. H. 7325, Gen. Assemb., Reg. Sess. (R.I. 2016).

4. A. 08372, 238th Leg. Assemb., Reg. Sess. (N.Y. 2015).

5. H.B. 3252, 78th Leg. Assemb., Reg. Sess. (Or. 2015) [hereinafter H.B. 3252]; H.B. 3176, 78th Leg. Assemb., Reg. Sess. (Or. 2015) [hereinafter H.B. 3176].

6. Initiative No. 732 (filed 20 March 2015)

7. H.B. 3252.

8. H. 412, 73rd Gen. Assemb., Biennial Sess. (Vt. 2015-16) [hereinafter H. 412]; H. 395, 73rd Gen. Assemb., Biennial Sess. (Vt. 2015-16) [hereinafter H. 395]; Initiative No. 732 (filed 20 March 2015).

9. S. 1747 .

10. H.B. 3176.

11. http://www.rggi.org/rggi.

12. Under the Washington proposal, the tax would increase to $\$ 25$ in the second year and then rise slowly at the rate of inflation plus 3.5 percent a year to an eventual maximum of $\$ 100$.

13. Oregon Constitution, Article IX $\S 3 \mathrm{~b}$. For a history of this provision, see Northwest Natural Gas Company v. Frank, 648 P.2d 1284, 1285-86 (Or. 1982).

14. Cf. Northwest Natural Gas Co. v. Frank, 648 P.2d 1284, 1285 (Or. 1982) (constitutional limit applies to energy tax based on BTUs).

15. The 1980 amendment is ambiguous as to whether it applies to all levies on oil and natural gas, or only on oil and natural gas "produced or salvaged" from Oregon. See Northwest Natural Gas Co. v. Frank, 648 P.2d 1284, 1288 (Or. 1982).

16. Oregon produced 950 million cubic feet of natural gas in 2014. Natural Gas Gross Withdrawals and Production, U.S. Energy Info. Admin., https://www.eia.gov/dnav/ng/ ng_prod_sum_a_EPG0_VGM_mmcf_a.htm (last visited 11 November 2016). The end use consumption of natural gas in Oregon in 2014 was about 220,090 million cubic feet. Natural Gas Consumption by End Use: Oregon, U.S. Energy Info. Admin., https://www. eia.gov/dnav/ng/ng_cons_sum_dcu_SOR_a.htm (last visited 11 November 2016).

17. If the constitutional provision applies to all oil and natural gas, regardless of place of production, the limit could be much lower than 6 percent, because the limit is defined in terms of 6 percent of the fair market value of oil and gas produced in state. If out-ofstate oil and gas is included in the tax base, the limit on the aggregate tax might be equal to 6 percent of just the tax on in-state fuels, which would yield a considerably lower tax rate. See Office of the Attorney General, 41. Or. Op. Atty. Gen. 552 (Or. A.G.), Opinion No. 8042 (30 June 1981).

18. Oregon Constitution, Article VIII § 2(1)(g).

19. Id. Article IX § 3a.

20. Rogers v. Lane County, 771 P.2d 254, 257 (Or. 1989) (quoting State ex rel. Sprague v. Straub, 400 P.2d 229 (1965)).

21. See, e.g., Massachusetts Constitution art. LXXVIII; New Hampshire Constitution pt. 2 , art. 6-a.

22. H.B. $3252, \S(2)(b)(2)$. Because the bill cross references the constitution language, it does not explicitly distinguish between fuel produced in-state and fuel produced out-of-state.

23. H.B. $3176 \S 4(6)$.

24. H.B. $3252 \S 3(1)$ (a)-(c).

25. Automobile Club of Oregon v. State, 840 P.2d 674, 681 (Or. 1992); Rogers v. Lane County, 771 P.2d 254, 259 (Or. 1989).

26. See Automobile Club of Oregon v. State, 840 P.2d 674 (Or. 1992). 
27. H.B. $3252 \S 3(2)(a)-(c)$.

28. H.B. $3176 \S 6(2)$.

29. See H.B. $3176 \S 4(6)$ (providing a constitutional savings clause for only what fuels can be taxed, but failing to provide a savings clause for a constitutionally permissible use of the revenue).

30. Automobile Club of Oregon v. State, 840 P.2d 674, 682 (Or. 1992).

31. See H.J.R. 10, 78th Leg. Assemb., Reg. Sess. (Or. 2015) (House Joint Resolution presented to amend the constitution and permit the legislature to tax carbon based fuels, which never passed).

32. Opinion of the Justices to the House of Representatives, 32 N.E.3d 287, 294 (Ma. 2015).

33. A separate issue, not addressed here, is the scope of the Senate's power to amend a bill that originates in the House. See, e.g., City of Seattle v. Department of Revenue, 357 P.3d 979 (Or. 2015).

34. Massachusetts Constitution, Part II, c. $1, \S 3$, art. 7.

35. Oregon Constitution, art. IV, $\S 18$.

36. U.S. Constitution, art. I, $\S 7$, cl. 1 .

37. Vermont Constitution, Chapter II, $\S 6$.

38. Washington Constitution, $\S 20$.

39. Northern Counties Investment Trust v. Sears, 41 P. 931, 935 (Or. 1895).

40. Opinion of the Justices to the House of Representatives, 32 N.E.3d 287, 295 (Mass. 2015) (quoting Opinion of the Justices, 126 Mass. 557, 601 (1878)).

41. Cited in, e.g., United States v. Norton, 91 U.S. 566, 569 (1875); Opinion of the Justices, 32 N.E.3d 287, 295 n.19 (Ma. 2015); Bobo v. Kulongoski, 107 P.3d 18, 23 (Or. 2005); Opinion of the Justices, 152 N.E.2d 90, 95 (Ma. 1958); Northern Counties Investment Trust v. Sears, 41 P. 931, 935 (1895).

42. Northern Counties Investment Trust v. Sears, 41 P. 931, 936 (Or. 1895).

43. Emerson College v. City of Boston, 462 N.E.2d 1098, 1105 (Mass. 1984) ("Ultimately, however, the nature of a monetary exaction 'must be determined by its operation rather than its specially descriptive phrase."' (citation omitted)). $C f$. Nat'l Fed'n of Indep. Bus. v. Sebelius, 132 S. Ct. 2566, 2596 (2012) (a "shared responsibility payment" or "penalty" for the failure to purchase insurance under Obamacare was in fact a "tax" for federal constitutional purposes); United States v. La Franca, 282 U.S. 568, 272 (1931) ("[n]o mere exercise of the art of lexicography can alter the essential nature of an act or a thing."); Automobile Club v. State, 840 P.2d 674, 679 (Or. 1992) (legislature's use of "assessment" rather than "tax" is "important but not dispositive" for purposes of a revenue-dedication provision governing motor vehicle fuel taxes in the state constitution). Although these constitutional law cases did not involve the origination clause, there is no reason to think that their rationales would not apply to the origination clause.

44. Opinion of the Justices to the House of Representatives, 32 N.E.3d 287, 296 (Mass. 2015) (citing a prior advisory decision and quoting a US Supreme Court case).

45. Id. at 297 .

46. Bobo v. Kulongoski, 107 P.3d 18, 24 (Or. 2005).

47. City of Seattle v. Department of Revenue, 357 P.3d 979, 987-88 (Or. 2015).

48. See Sissel v. U.S. Department of Health and Human Services, No. 13-5202 (D.C. Circuit, 29 July 2014), slip op. at 13 (penalty to encourage people to purchase health insurance under the "Obamacare" health insurance law was deemed to be a tax but was not subject to the federal origination clause; the $\$ 4$ billion in projected annual "revenues are a byproduct of the Affordable Care Act's primary purpose to induce participation in health insurance plans").

49. Oregon Constitution, art. IV $\S 25(2)$.

50. H.B. 3176; H.B. 3252.

51. California Chamber of Commerce v. California Air Resources Board, Case No. 34-2012-80001313, Joint Ruling on Submitted Matters, 28 August 2013, slip op. at 2.

52. California constitution, art. XIIIA, $\S 3$ (prior to amendment). As a result of a 2010 
amendment, the constitution defines taxes as "any levy, charge or exaction of any kind imposed by the State" with the exception of certain payments, such as charges that confer benefits to the payers and do not exceed the State's reasonable costs, charges for government services or products to the payers that do not exceed the State's reasonable costs, and charges for reasonable regulatory costs. Id. art. XIIIA, $\S 3$. Because the law pre-dated the 2010 constitutional amendment, the case is being litigated under the original language quoted above.

53. See California Chamber of Commerce v. California Air Resources Board, Case No. 34-2012-80001313, Joint Ruling on Submitted Matters, 28 August 2013, slip op. at 13.

54. Id. at 19 .

55. California Chamber of Commerce v. California Air Resources Board, C075930, Sacramento County, No. 34201280001313CUWMGDS, consolidated with Morning Star Packing Company v. California Air Resources Board, C075954, Sacramento County, No. 34201380001464CUWMGDS.

56. Washington Constitution, art. II, § 1(a).

57. Wash. Rev. Code Ann. §29A.72.010 (West 2016).

58. Id. § 29A.72.150.

59. Id. § 29A.72.260.

60. Washington State Secretary of State, Voters' Guide General Election 2016, https:// weiapplets.sos.wa.gov/MyVoteOLVR/OnlineVotersGuide/Measures?language=en\&el ectionId $=63 \&$ countyCode $=x x \&$ ismyVote $=$ False\&electionTitle $=2016 \% 20$ General $\% 20$ Election\%20\#ososTop http://yeson732.org/introducing-initiative-i-732-come-say-hello -today-or-tomorrow/.

61. Washington State Secretary of State, 8 November 2016 General Election Results, http://results.vote.wa.gov/results/20161108/State-Measures-Initiative-Measure-No732-concerns-taxes.html.

62. Note that initiatives in Washington can also follow a different path as "initiatives to the people". 